\title{
STEAM Course Development and Design based on Design Thinking: A Case Study on "Self-induction Demonstrator"
}

\author{
Zhi $\mathrm{Li}^{1}$, Yaxi Zhang1, Meiqi Yu ${ }^{1}$, Yue Zhang1, Xinyu Wang ${ }^{1}$, Zhemin $\mathrm{Wu}^{1}$, and Li Xie ${ }^{1, *}$ \\ ${ }^{1}$ School of Physics and Optoelectronic Engineering, Yangtze University, Jingzhou 434023, China \\ *Corresponding Author: shirlyxieli@yahoo.com
}

(Received: 09/04/2021; Accepted: 12/07/2021; Published: 12/16/2021)

DOI: https://doi.org/10.37906/real.2021.5

\begin{abstract}
STEAM education is a new direction of education reform in the 21st century. It can cultivate students' ability to creatively solve practical problems, integrate and apply interdisciplinary knowledge. It is an effective way to help students master the 21st century's abilities. All countries spare no effort to let it be local Take root. The integration of design thinking and STEAM education provides a good opportunity for students' comprehensive and creative development. Therefore, we use the D. School design thinking model developed by Stanford University to develop a STEAM course based on design thinking to improve students' STEAM literacy and the skills and abilities that company needs for high-quality development. This STEAM course takes "Self-induction Demonstrator" as the project theme, including five steps: Empathize, Define, Ideal, Prototype, and Test. It aims to provide a reference paradigm for the design and implementation of the K-12 STEAM course, and promote the deep integration of science, technology, engineering, mathematics and art.
\end{abstract}

Keywords: Design Thinking, STEAM Education, D. School Model, Curriculum Project Design

\section{Introduction}

With the world globalization, competition among different countries has intensified, especially in some fields that represent the country's overall strength - science and technology, economy, manufacturing, materials, etc. Countries have devoted more capital to education to improve their international competitiveness and influence. In addition to industrial manufacturing, introducing foreign technology, and deploying strategic industries, STEM education (science, technology, engineering, mathematics) is also an area of national focus. President Obama invested significant capital in recruiting and training STEM teachers through public-private collaboration, and the U.S. Department of Education also provided generous bonuses for STEM teaching through competitions (Piro, 2010). As a new direction of education reform in the 21st century, STEAM education can train students' creativity and innovation skill, and is closely related to the future of economics (Godin, 2008). Creativity and innovation skill is one of the necessary skills for students in the 21st century (the others are Critical-thinking and Problem-solving, Communication, and Collaboration). Maria Miller, the Minister of Culture, publicly stated: "Culture and innovation have played an important role in the education of children. We should discuss and emphasize the importance of STEAM education." (Wang, Wang, \& Sun, 2017). The most important step in promoting the agenda of publicizing and enhancing the importance of art discipline is to vigorously advocate the values of STEAM and increase the influence of art (Liao, 2016).

The development and application of STEAM courses is directly related to knowledge integration. It is shown that the integration of subject knowledge in science and art is beneficial to STEM or STEAM teachers in creatively designing teaching goals, formulating teaching strategies, and implementing teaching 
evaluations (Piro, 2010). STEAM courses should pay more attention to cultivating students' critical thinking and the ability to creatively solve problems. However, science teachers and art teachers mostly use the knowledge of independent subjects to teach in the K-12 stage. They are unfamiliar with exploring the internal connections between various subjects and lack the ability to integrate interdisciplinary knowledge. Faced with such a dilemma, design thinking brings a silver-lining. Design thinking provides students with opportunities to creatively redefine and redesign solutions, and provides teachers with a way to stimulate and hone creative problem-solving skills (Kristin Cook, 2018). Design thinking and STEAM education are ideologically compatible. They both emphasize integration, comprehensiveness, interdisciplinary, situational, creativity of knowledge and the ability to solve practical problems. There are many discussions about design thinking in the education field, and they all focus on the application of design thinking in normalized teaching. The scope of application includes: teaching objectives, teaching content, teaching methods, teaching process, teaching effects, teaching evaluation, etc. But this discussion was still unclear, because there is no specific explanation on how designs and education are related in educational practice (Henriksen, 2017). Whether majored in science or art, they have become an amateur in the face of design thinking because they are not experts in design field. They are faced the same dilemma as the rise of STEM education: experience. Therefore, this paper designs a STEAM course with "Self-induction Demonstrator" as the project theme on the basis of clarifying the connotation, characteristics, and basic modes of design thinking. On one hand, it improves students' STEM/STEAM literacy and help them master 21st century skills, so as to let them become the innovative talents needed for the high-quality development of the enterprise in the future. On the other hand, it provides certain reference and experience in teachers to develop and apply STEAM courses based on design thinking.

\section{2. literature review}

\subsection{STEAM education}

The predecessor of STEAM education was the STAM education proposed by the United States in the 1990s. It adds "Art" on the basis of the original STEM education. Art includes a wide range of humanities and arts subjects, covering social studies, language, physical, musical, fine and performing, etc., all of which helped students understand the connection between different disciplines from a more holistic perspective, and improve their ability to comprehensively use knowledge to solve practical problems (Zhao \& Lu, 2016). Obama vigorously promoted the implementation of this comprehensive curriculum. It aims to cultivate students' hands-on, innovative and comprehensive use of scientific knowledge from an early age (Fu \& Wang, 2014). With the increasingly fierce international competition in science and technology, interdisciplinary talents have gradually become the key to the international game battlefield. In order to vigorously improve their international competitiveness, promote the frontier development of science and technology and the steady increase of the national economy, countries have successively invested a large amount of financial and material resources to formulate corresponding policies to promote the localization of STEAM education, and comprehensively improve the STEAM literacy of the people to make them become innovative and comprehensive talents needed for the country. Schools in the United States, Canada, Israel and other countries have put more emphasis on the "experience" of science starting from the elementary school, emphasized the "learning by doing" in the field of science and technology, and improved innovation capabilities in the "experience" (Yan, 2020). The UK emphasizes that graduates trained by STEAM education must have strong imagination and innovation skills. The Creative Industries Federation, the Cultural Learning Alliance, the Arts Councils, and the sector skills agencies and NESTA should work together to achieve system-wide changes to solve the unique disciplinary islands in the education we provide for young people (Bakhshi \& Windsor, 2015). 
During the development of STEAM education, the development and research of teaching models followed one after another. As the origin of STEM, the United States has naturally invested a lot of energy in researching how to thoroughly implement the STEAM education concept in the K-12 stage, and launching a number of related teacher training projects and education concepts, such as "UTe -ach program", "design thinking in pedagogy" and "6E learning by design model" (Yan, 2020). With the prevalence of design thinking in the field of education in recent years, Henriksen believes that design thinking with its own openness and interdisciplinary characteristics can provide a guiding framework for STEAM teaching (Henriksen, 2017).

\subsection{Design thinking}

When design thinking was first proposed, it was understood as a way of thinking used by people in the design field, and the term "design thinking" was renamed back to the 1987 Harvard University architecture professor Rowe's book Design Thinking. Rowe sees it as a methodology that transforms the designer's ideas into objective entities (Rowe, 1987). After more than 30 years of development and evolution, it is now widely used in various industries and plays an important role in these fields, such as architecture, finance, consumption, art, education, etc. In the field of education, design thinking, as a constructivist learning method, helps to cultivate students' problem-solving skills, critical thinking skills, collaboration skills, communication skills, empathy and social responsibility, so that students can calmly solve complex problems of daily life and lay a solid foundation for students' future growth (Qiao \& Sun, 2020).

Design thinking can take root in all walks of life and fully realize its commercial value. This is inseparable from its people-oriented concept, as well as the development and research of its application models. With the continuous expansion of design thinking fields, many different forms of design thinking models have emerged from recent years, mainly divided into IDEO (Tim \& Katz, 2011), IBM (Ingo \& Schmiedgen, 2015), GDS (Richard \& Wax, 2015), and D. School (Plattner, 2015), HPI D-School (Katja \& Roland, 2011), DFC (Change, 2013), etc. Among them, the D. School design thinking model is a diversified design method rooted in technological product innovation, problem-solving as a driving force, and attention to user experience. It can effectively promote the development of learners' thinking ability and improve existing products. The transformation of scientific and technological achievements and the generation of innovative products provide strong support (Yang \& Shen, 2018), which has become one of the commonly used design patterns in the education field. The D. School design thinking model mainly includes five steps of empathy, definition, conception, prototype, and testing (see Fig.1). These five steps are not independent individuals. They are interconnected with each other to form an iterative linear relationship (Christoph \& Hasso, 2017), the details are as follows: 

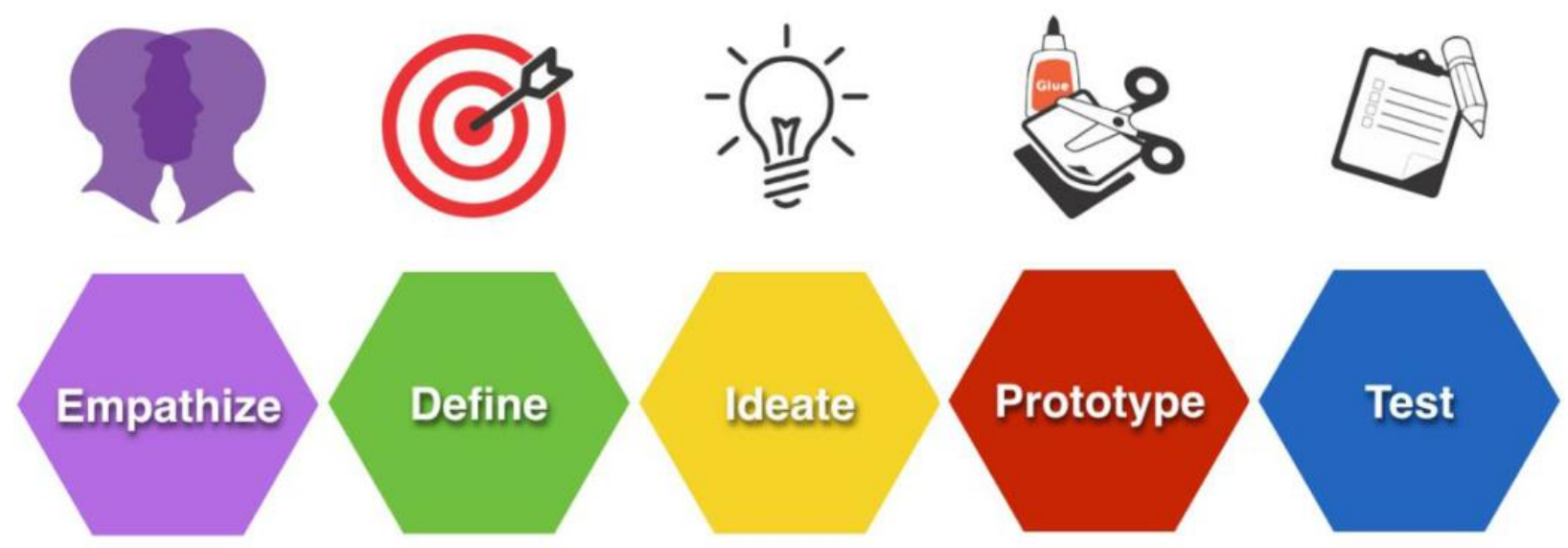

Figure 1. This picture is adopted from Danah Henriksen (2017), which shows the Process of D. School Design Thinking Model

(1) Empathize

Empathize is the first and core step, because it requires designers to think from the perspective of people or product audiences, fully taking into account their needs and views on the product, or what problems existing products have caused if they had a bad experience. Therefore, behavior observation, questionnaire surveys, and semi-structured interviews are excellent tools to allow designers to collect user needs and questions from many aspects. The needs and problems of users are often the most concerned by designers, because these are necessary prerequisite for smoothly carrying out the remaining steps. This is why the essence of design thinking is a methodology to help designers solve practical problems.

(2) Define

Define is the second step in the implementation of design thinking. The designer should aggregate the user opinions, needs, and problems collected in the Empathize to gain an in-depth understanding of the internal connections between them. Then clarify the shared needs and individual needs from product audience. It is worth mentioning that the problem here stems from user dissatisfaction with the product or product damaged due to poor quality. After that, the designer generates a clear definition of the problem based on a full understanding of the user's point of view. Defining a problem is not simply a stack of collected information. It is caused by the collision between the designer's knowledge and experience and the user's actual problem. The clearer and more accurate the problem definition, the more conducive to the solution of the problem.

(3) Ideate

Ideate is a bridge between the problem and the solution. The designer's way of thinking will not be constrained by a single framework in this step. Here, any multi-dimensional and multi-dimensional ideas can be accepted, but these ideas must all point to the problem. In addition to giving full play to their imagination and creativity, they can also use user maps, brainstorming and graphical thinking to concretize their thoughts and wants, so as to make this bridge more stable and solid to facilitate subsequent processes.

\section{(4) Prototype}

This is the step where the designer turns the conception of the scheme into an objective entity, but this is only the prototype of the finished product. There is still a distance from the formal product. The way designers put ideas into practice is diverse. It can be to make a physical object or to write a software specification. It depends on the needs and problems identified with the Empathize and Define. 


\section{(5) Test}

The step of Prototype will inevitably expose factors that were not considered when the plan was originally conceived. The Test is to reconsider and design these factors. Only the prototype that successfully passes the test can become the final product to be loved by the product audience. Therefore, the designer can not only review the first four aspects of design thinking and re-adjust, but also show his product to the product audience. Or let them personally test the product to understand whether the designer's final product meets their needs and whether it solves the problems they raised. As mentioned earlier, the five steps to the D.School design thinking model are not independent. On the contrary, they are closely connected. If the product has defects in the Test and cannot be improved, the modified product will return to the Prototype. It may be necessary to return to the Define, or even the Empathize, for redesign.

The biggest feature of D.School design thinking model is knowledge integration, which allows students to learn to think about problems with multiple perspectives instead of staying in a single perspective. Knowledge integration is a major trend in future education. The National Academies of Sciences, Engineering, and Medicine (2018) survey shows that employers prefer people who have developed in all aspects. They can face difficulties calmly and analyze problems of many aspects (David \& Bear, 2018). STEAM learning is about enriching and integrating topics in an interdisciplinary manner, allowing people to participate in creativity, problem solving, and project-based or problem-based learning in real-world impact issues (Danah \& Swati, 2019). Integrating design thinking into the STEAM curriculum is more conducive to the development of students.

\subsection{1 st century skills}

The era of fierce competition has not only brought new enlightenment to the global basic education reform, but also put forward new requirements for students. Partnership for 21st Century Learning has revised the previous framework for 21st century learning, which has attracted extensive attention and attention from the international education community (Wang, 2020).Different from the 3R (i.e. reading, writing and innovation) skills valued in the 19th-20th century, the 21st century skills belong to high-level skills, mainly focusing on critical thinking and problem solving, communication, collaboration, creativity and innovation (i.e. 4C skills) (Deng \& Peng, 2019a). They are more related to the needs of emerging economic and social development models (Katerina \& Magdalena, 2009), which also means that the reform orientation of basic education curriculum has changed from knowledge-based to skill-based. USA, OECD, EU, Korea, Australia and other countries have also successively integrated 21st century skills into corresponding national curriculum policies, and further implemented and evaluated these skills in educational practice (Joe \& Natalie, 2012).

Integrating 21st century skills into middle school science curriculum is conducive to students' in-depth understanding of knowledge in real situations, rather than staying on the surface of knowledge, and can also improve students' tendency towards active learning (Rhonda \& Gerald, 2015). Project-based learning, STEM / STEAM education and Inquiry-based learning are all regarded as viable ways to develop students' skills in the 21st century (Yasemin, 2021; Deng \& Peng, 2019b). These methods can further develop students' high-level thinking, promote the transfer and application of knowledge to the actual situation, and cultivate high-level talents that serve to improve and maintain the country's dominant position in the global competition.

\section{STEAM course design based on design thinking}

With the frontier development of science and technology, the phenomenon of electromagnetic induction has become more closely related to modern life, and its wide application in electrical engineering,

electronic technology, electrification, and automation has played an important role in promoting the 
development of social productivity and science and technology. Electromagnetic induction is an important field for the development of national science and technology, but there is a lack of high-quality innovative talents in this field. Therefore, it is very necessary to design the STEAM course with electromagnetic induction as the theme, which also lays the foundation for students' future career choices. In the case of the STEAM course, the second-year high school students, supported by the concept of design thinking, took the "Self-induction Demonstrator" as the project theme and combined the materials provided by the laboratory to design. This requires students to make full use of knowledge in other fields (technology, engineering, art and mathematics) on the basis of physics knowledge to complete the design, integrate the knowledge of different disciplines and use it to solve practical problems. The full integration of design thinking and STEAM courses is a prerequisite to ensure the effective implementation of STEAM courses. Therefore, it is necessary to establish the relationship between Design thinking process, STEAM knowledge, and 21st century skills involved (see Table 1).

Table 1. STEAM knowledge, Design thinking process and 21st century skills involved in the project theme of " Self-induction Demonstrator"

\begin{tabular}{|c|c|c|c|}
\hline $\begin{array}{l}\text { Design thinking } \\
\text { process }\end{array}$ & Investigated elements & STEAM & 21st century skills(4Cs) \\
\hline Empathize & $\begin{array}{l}\text { Knowledge of psychology and } \\
\text { electromagnetism, Preparation and } \\
\text { measurement of questionnaire and basic } \\
\text { operation of computer, Engineering } \\
\text { thinking (finding problems and } \\
\text { interference factors), Process design, Data } \\
\text { statistics and analysis }\end{array}$ & $\begin{array}{c}\text { Science } \\
\text { Technology } \\
\text { Engineering } \\
\text { Art } \\
\text { Mathematics }\end{array}$ & $\begin{array}{l}\text { Critical-thinking and } \\
\text { Problem-solving } \\
\text { Communication } \\
\text { Collaboration }\end{array}$ \\
\hline Define & $\begin{array}{l}\text { Information screening, analysis and } \\
\text { synthesis, communication and expression } \\
\text { skills }\end{array}$ & $\begin{array}{l}\text { Engineering } \\
\text { Art } \\
\text { Mathematics }\end{array}$ & $\begin{array}{c}\text { Creativity and Innovation } \\
\text { Critical-thinking and } \\
\text { Problem-solving } \\
\text { Communication } \\
\text { Collaboration }\end{array}$ \\
\hline Ideate & $\begin{array}{l}\text { Model and scheme design, circuit layout } \\
\text { and layout, material selection and } \\
\text { collocation, supply-demand relationship, } \\
\text { service conditions of components, } \\
\text { calculation of resistance and current, } \\
\text { algebraic operation and unit conversion }\end{array}$ & $\begin{array}{c}\text { Science } \\
\text { Technology } \\
\text { Engineering } \\
\text { Art } \\
\text { Mathematics }\end{array}$ & $\begin{array}{c}\text { Creativity and Innovation } \\
\text { Critical-thinking and } \\
\text { Problem-solving } \\
\text { Communication } \\
\text { Collaboration }\end{array}$ \\
\hline Prototype & $\begin{array}{l}\text { Application of transducers, electric drill, } \\
\text { cutting machine, polishing machine and } \\
\text { computer software; Hand cutting }\end{array}$ & $\begin{array}{l}\text { Technology } \\
\text { Engineering } \\
\text { Art }\end{array}$ & $\begin{array}{l}\text { Critical-thinking and } \\
\text { Problem-solving } \\
\text { Collaboration }\end{array}$ \\
\hline Test & $\begin{array}{l}\text { Product effect investigation, test and } \\
\text { optimization, display and introduction }\end{array}$ & $\begin{array}{c}\text { Science } \\
\text { Technology } \\
\text { Engineering } \\
\text { Art } \\
\text { Mathematics }\end{array}$ & $\begin{array}{l}\text { Critical-thinking and } \\
\text { Problem-solving } \\
\text { Communication } \\
\text { Collaboration }\end{array}$ \\
\hline
\end{tabular}

In this section, we explain how each steps of design thinking is represented in the "Self-induction Demonstrator" STEAM course. 


\subsection{Empathize}

Students need to understand that the audience of the product are students and teachers in the first step of the STEAM course, so as to design a "Self-induction Demonstrator" from their perspectives. Using interviews, questionnaires, access to materials, classroom observations, etc. to collect the needs and the problems of the product audience that need to be solved, and understand what functions the multifunctional electromagnetic induction demonstrator should have, how does it help students deeply understand electromagnetic induction, and how does it make it convenient for teachers to carry out demonstration experiments in many ways in the classroom. Then they found students who had already studied the phenomenon of self-induction, and knew the influence of teachers' demonstration experiments on their understanding of scientific knowledge. At the same time, they consulted the teacher about the existing demonstrator, and clarified the needs of students and teachers for the Self-induction Demonstrator:

a. The experimental phenomenon observed by the students was not obvious, and the demonstration effect was not good;

b. The teacher's presentation method is too single, and it is difficult for students to intuitively understand abstract electrical knowledge.

On the basis of observing the existing self-induction demonstrator, the students determined the design requirements of the product by combining the needs of students' learning and the needs of teachers' teaching. The Empathize step of design thinking mainly allows students to fully experience the relationship between the needs of students and teachers and products from the perspective of users, cultivate their ability to discover and solve problems, and stimulate students' curiosity for science.

\subsection{Define}

In order to effectively enhance students' awareness of teamwork, teachers organize students to report the collected information in groups. Before the formal report, each team need to screen, analyze and synthesize the needs and problems of the product audience to avoid deviations in the design direction caused by misinformation. After the report, the whole class will have a group discussion for about 20 minutes to ensure that they can reach a consensus on the needs of students and teachers, so as to ensure the smooth progress of the design of the Self-induction Demonstrator. After the discussion, it is determined that the "Self-induction Demonstrator" designed this time needs to achieve the following functions:

a. Combine traditional demonstration experiment and digital experiment to reflect the concept of integrated education.

b. The experimental equipment is innovative and breaks the thinking set.

c. The experimental equipment is simple in structure to facilitate teachers to demonstrate operations and demonstrations in the classroom.

Therefore, the problem to be solved is divided into three parts: effect; innovation; convenience.

\subsection{Ideate}

Imagination and creativity are key elements for practicing the concept of design thinking. On the basis of understanding the principle of self-induction, each group member uses brainstorming, associations, graphical thinking, etc. to propose their own ideas or plans. For example, in order to realize the multidimensional function of the "Self-inductance Demonstrator", can we use experimental data (observation data vs numerical data) to characterize experimental effects (phenomenon vs numbers)? After the discussion, students use a paper to present the need to solve and how to solve. The problems and solutions represented in paper is shown in Fig.2. 


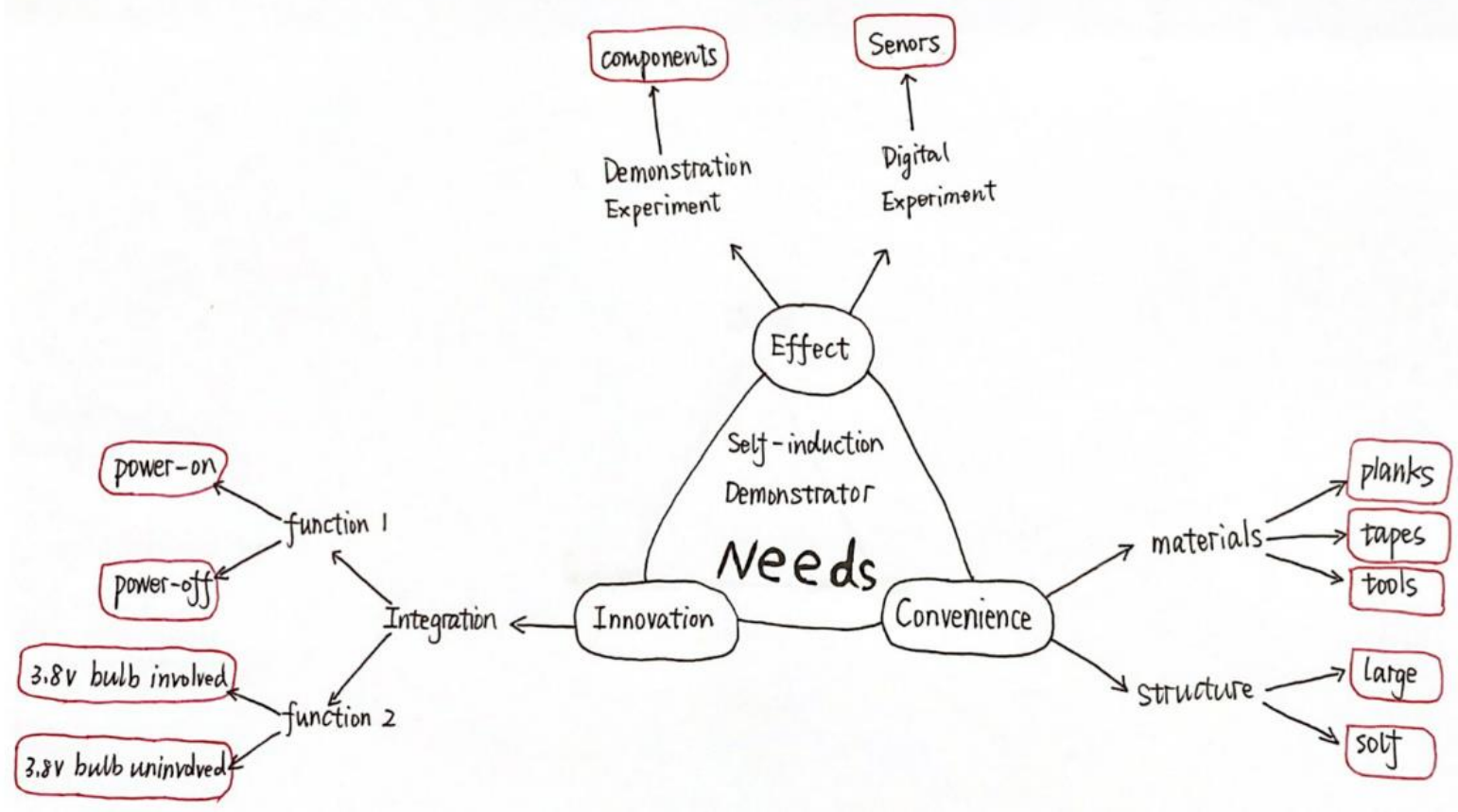

Figure 2. The solution presented by the students in the Ideate step, black represents the problems and red represents the solutions

\subsection{Prototype}

Prototype provides students with an opportunity to transform their ideas and plans into for objective entities. Once the design plan is determined, students need to think about what materials should be selected for production. The laboratory can provide students with enough materials to help them with experimental design, such as: adjustable power, $3.8 \mathrm{~V}$ bulb, detachable transformers, electric drills, sensors, $45 \mathrm{~cm}$ by $30 \mathrm{~cm}$ wooden boards, screwdrivers, etc. Due to the specificity of electrical components, students need to consider the applicable conditions of the components to avoid excessive voltage or current causing damage to the components and the failure of the instructor's experimental design. Then, students only need to select materials for product production according to the plan, and design the circuit diagram of the "Selfinduction Demonstrator" on paper and board (see Fig.3), and use the electric drill provided by the laboratory to build the components on the wooden board. In this step, students should fully consider the actual size and thickness of the components and ensure the simplicity of the layout of the entire presentation interface. This is necessary to give full play to their own design thinking and artistic aesthetics, and hide the wiring of all components behind the wooden board. Fig. 4 is the prototype made by students in the laboratory. It can initially realize the self-inductance phenomenon of power-on and self-inductance of power-off, so as to solve the "Effect" requirement of the demonstrator. 

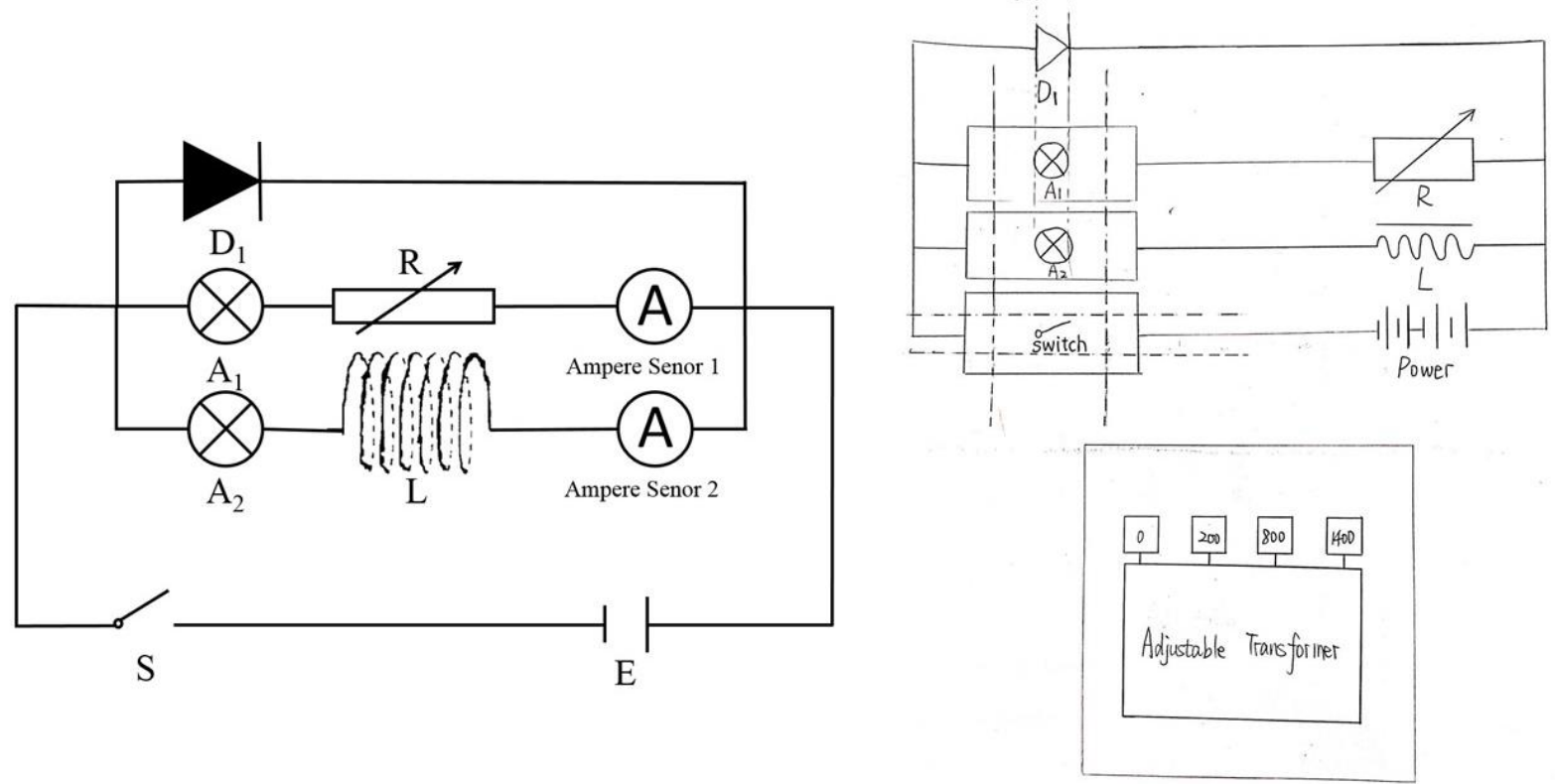

Figure 3. Part of the circuit designed by the students on the board

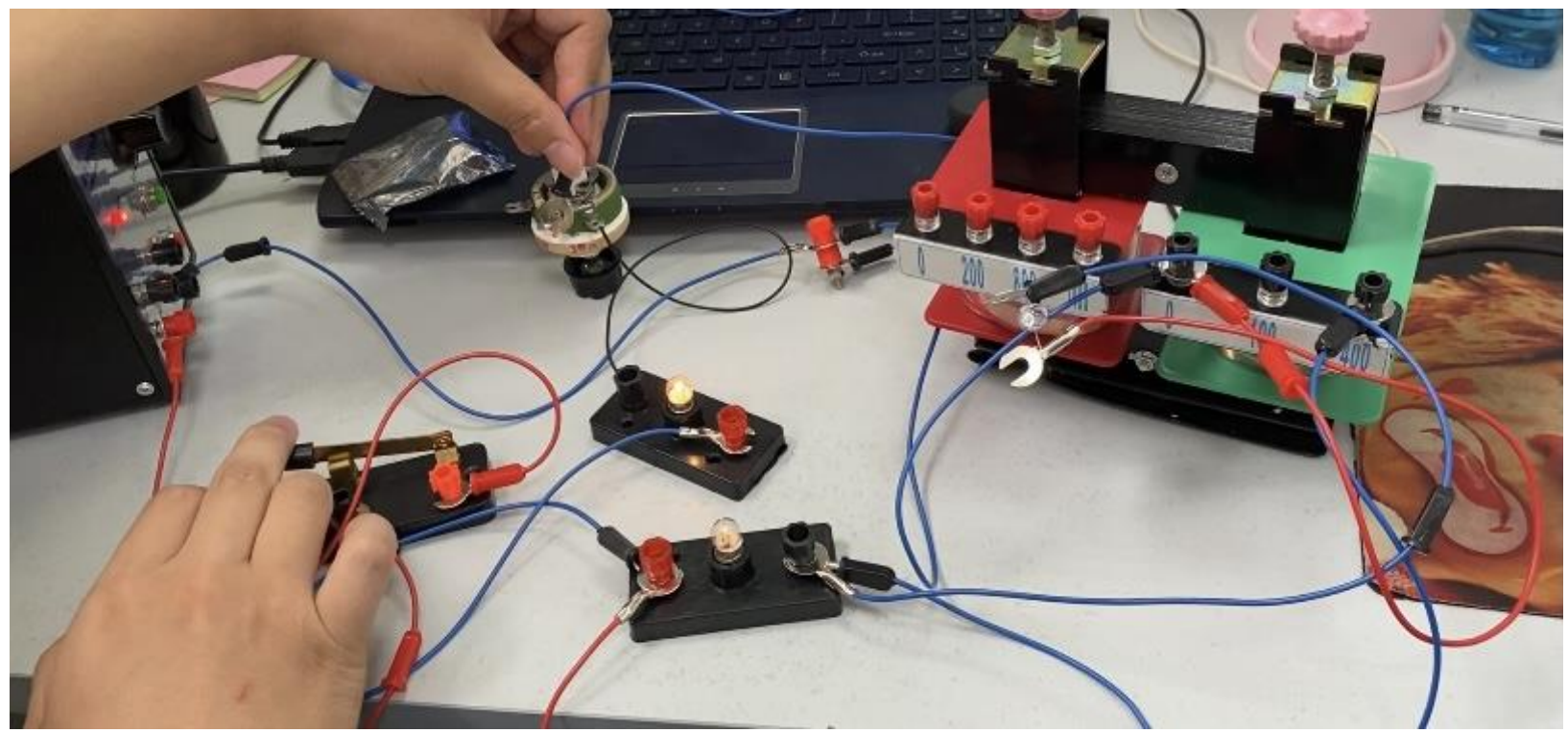

Figure 4. The prototype of the " Self-induction Demonstrator" designed by students

\subsection{Test}

The birth to every excellent product is inseparable from the exploration of failure. Students need to optimize and improve the prototype many times to ensure the perfect solution of the above three problems. During this period, students get to the product audience's feedback and evaluation of the prototype. They will continue to explore the optimal design of the product. For example, during this design process, there were problems in the circuit designed by the students, which caused the numerical data phenomenon to be not obvious (the "Effect" problem was not solved), and the value of the electric current was not reached. Therefore, it was necessary to re-improve the circuit (the finished product and the digital experiment display is shown in Fig.5). Finally, the students showed the "self-induction demonstrator" they designed to the product audience, and introduced the functions it can achieve (qualitative and quantitative 
demonstration; both power-on self-induction and power-off self-induction are presented at the same time; explore the influence of small bulb on self-induction).

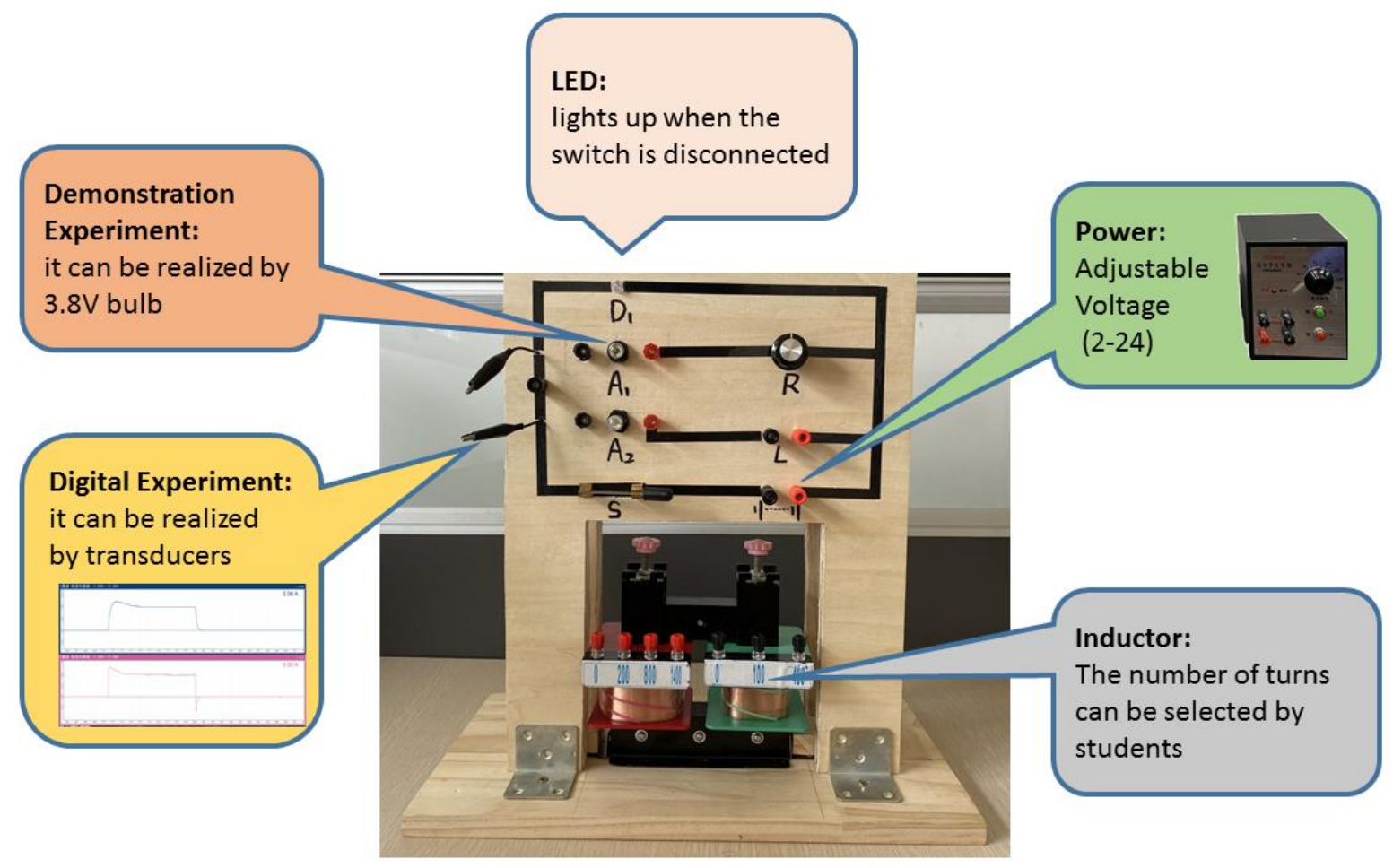

Figure 5. This is a picture showing the "Self-induction Demonstrator" designed by students

\section{Conclusion and reflection}

The production of the "Self-induction Demonstrator" STEAM project based on design thinking not only provides opportunities for students to use interdisciplinary knowledge to solve practical problems, but also allows students to personally design plans according to user needs and carry out unreasonable design. Modifications and corrections require students to deal with these problems in a more rigorous, comprehensive, and scientific manner. This is more capable of cultivating students' higher-order thinking and 21st century skills than traditional teaching that focuses on knowledge. A knowledge-based society needs talents with diversity and creativity that can generate unique, practical and intelligent values, not just grow talents such as technicians or intellectuals (Yilip \& Namje, 2012). The skills and innovation capabilities necessary for the future society cultivated by STEM education may continue to play a role in the future life and work of learners. The integration of art on this basis can break the barriers of various disciplines and establish the internal connection between different disciplines. This provides a possible path for cultivating the comprehensive talents needed by the society in the future.

Nevertheless, this study has some limitations. First, due to differences in educational resources, financial allocations, teacher quality, and school quality in different regions, the curriculum design cases in this study have not been implemented in multiple regions. In other words, the "Self-induction Demonstrator" STEAM course cannot be guaranteed universality. Second, there is a lack of scientific data. The changes in students' related skills, abilities, and professional attitudes before and after class are important evidence to verify the effectiveness of STEAM courses. Therefore, it is necessary for future research to compile corresponding questionnaires to explore students' Variety. Third, the curriculum 
design does not reflect the concept of advanced learning. The real scientific learning process is complicated. The development of student core literacy is the result of the interaction of multiple factors, often combining the cultivation of multiple key abilities under a certain theme. The cultivation of a certain key ability needs to be repeated under multiple topics with different focuses (Guo \& Yao, 2016). The development of advanced courses can better help students integrate fragmented knowledge one by one. The design integrated into the STEAM curriculum group is also an area that science educators need to study in depth.

\section{Reference:}

Bakhshi, H., \& Windsor, G. (2015, April 21). NESTA. Retrieved from The creative economy and the future of employment:

https://media.nesta.org.uk/documents/the_creative_economy_and_the_future_of_employment.p df.

Change, D. f. (2013). Design for change curriculum. Retrieved from Design for change: http://www.designforchange.us/dfcusa/files/Design\%20for\%20Change\%20USA\%20-\%20Curricul um.pdf.

Christoph, M., Larry, L., \& Hasso, P. (2017). Design thinking: understand-improve-apply. Springer Science \& Business Media.

Danah, H., Rohit, M., \& Swati, M. (2019). Design Thinking Gives STEAM to Teaching: A Framework That Breaks Disciplinary Boundaries. Springer.

David, S., \& Bear, A. (2018). The Integration of the Humanities and Arts with Sciences, Engineering, and Medicine in Higher Education: Branches from the Same Tree. Washington,DC: THE NATIONAL ACADEMIES PRESS.

DENG, L., \& PENG, Z. (2019). Foster Global Competitiveness: An Inspection on Global 21th Century Skills Movement. Journal of Educational Science of Hunan Normal University, 18(2),89-98.

Deng, L., \& Peng, Z. (2019). Is Knowledge Prioritized or Skill?The Debates Over the Educational Reform of 21st Century Skills in United States. Research in Educational Development, 39(12),66-77.

Fan, Y., Yang, Y., Li, W., Gong, C., \& Xie, L. (2020). Exploring STEAM Education Activities Based on Project Production-A Case Study on "the Changeable Road" Project. Research in Education Assessment and Learning, 5(1),1-14.

FU, Q., \& WANG, C.-x. (2014). When Maker in STEAM Education . Modern Educational Technology, 24(10),37-42.

Godin, B. (2008). Science, Technology and Innovation : Intellectual and conceptual histories. Retrieved from CSIIC: http://www.csiic.ca/PDF/IntellectualNo1.pdf

Guo, Y., \& Yao, J. (2016). instructional design of science lessons based on the learning progression of key competencies. Curriculum,Teaching Material and Method, 36(11),64-70.

Henriksen, D. (2017). Creating STEAM with Design Thinking: Beyond STEM and Arts Integration. The STEAM Journal, 3(1),11-11.

Ingo, R., \& Schmiedgen, J. (2015). This is Design Thinking. Retrieved from How IBM made sense of 'generic design thinking' for tens of thousands of people: https://thisisdesignthinking.net/2019/07/ibm-design-thinking-adaptation-adoption-at-scale/\#zpID-3650-175089-M2EFSSK3 
JOKE, V., \& NATALIE, P. (2012). A Comparative Analysis of International Frameworks for 21st Century Competences: Implications for National Curriculum Policies. Journal of Curriculum Studies, 44(3),299-321.

Katerina, A., \& Magdalean, C. (2009). 21st Century Skills and Competences for New Millennium Learners in OECD Countries. OECD Education Working Papers.

Katja, T., \& Roland, M. M. (2011). Understanding design thinking: A process model based on method engineering. INTERNATIONAL CONFERENCE ON ENGINEERING AND PRODUCT DESIGN EDUCATION, (pp. 493-498).

Kristin, C., \& Bush, S. B. (2018). Design thinking in integrated STEAM learning: Surveying the landscape and exploring exemplars in elementary grades. School Science and Mathematics, 93-103, 118(34),93-103.

Liao, C. (2016). From Interdisciplinary to Transdisciplinary: An Arts-Integrated Approach to STEAM Education. Art Education, 69(6), 44-49.

Piro, J. (2010). Going From STEM to STEAM The Arts Have a Role in America's Future, Too. Education Week, 28-29, 29(24),28-29.

Plattner, H. (2015). Bootcamp bootleg. Retrieved from Institute of Design at Stanford: https://dschool.stanford.edu/wp-content/uploads/2011/03/BootcampBootleg2010v2SLIM.pdf

QIAO, F., WU, T., \& SUN, Y. (2020). Design Thinking and Innovation Education . Beijing: Science Press .

Rhonda, C., \& Gerald, K. (2015). Active Learning Approaches to Integrating Technology into a Middle School Scince Curriculum Based on 21st Century Skills. Springer International Publishing.

Richard.Banfield, C Todd, L., \& Wax, T. (2015). Design sprint: A practical guidebook for building great digital products. O'Reilly.

Rowe, P. G. (1987). Design thinking. Cambridge: MIT Press.

Tim, B., \& Katz, B. (2011). Change by Design. Journal of product innovation management, 28(3),381-383.

Wang, S. (2020). The 21st century skills goal in the mission statement of American public high schools: Interpretation and Reflection Based on text coding analysis. Journal of World Education, 33(10),72-77.

WANG, X., Wang, L., \& Sun, H. (2017). From STEM to STEAM: The Innovative Road for Education in UK. International and Comparative Education, 39(10),3-9.

YANG, X., \& SHEN, S. (2018). Study on Maker Education Practice Supported by Design Thinking Method. E-education Research, 39(02):74-79.

Yang, Y., Fan, Y., Lu, H., Yuan, H., \& Xie, L. (2020). New Attempt of Curriculum Reform- A Case Study of Physics STEAM Curriculum in a Senior High School. Research in Education, Assessment, and Learning, 6(1),1-14.

Yasemin, H. (2021). The Effect of STEM Education on 21st Century Skills: Preservice Science Teachers' Evaluations. Journal of STEAM Education, 4(2),140-167.

Yilip, K., \& Namje, P. (2012). The Effect of STEAM Education on Elementary School Student's Creativity Improvement. Communications in Computer and Information Science, 1(339),115-121. 
ZHAO, H., \& LU, X. (2016). lmplementing STEAM Education and lmproving the Students' lnnovation Ability : An Interview with the STEAM Education Scholars Georgette Yakman in USA. Open Education Research, 22(05),4-10. 